\title{
Fogászati sérülésekről készült látleletek komplex terminológiai, fogászati és igazságügyi orvosszakértői elemzése
}

\author{
Bán Ágnes dr. ${ }^{1}$ - Patonai Zoltán dr. ${ }^{2}$ - Fogarasi Katalin dr. ${ }^{3}$ \\ Schneider Philipp dr. ${ }^{4}$ - Boda Róbert dr. ${ }^{5}$ - Gergely Péter $\mathrm{dr} .{ }^{6}$ \\ Pécsi Orvostudományi Egyetem, ${ }^{1}$ Klinikai Központ, Fogászati és Szájsebészeti Klinika, \\ ${ }^{2}$ Klinikai Központ, Traumatológiai és Kézsebészeti Klinika, \\ ${ }^{3}$ Semmelweis Egyetem, Nyelvi Kommunikációs Igazgatóság, Budapest \\ ${ }^{4}$ Pécsi Tudományegyetem, Jogtudományi Kar, Kriminológiai és Büntetés-végrehajtási Jogi Tanszék, Pécs \\ Debreceni Egyetem, ${ }^{5}$ Fogorvostudományi Kar, Arc-, Állcsont- és Szájsebészeti Tanszék, \\ ${ }^{\circ}$ Általános Orvostudományi Kar, Igazságügyi Orvostani Intézet, Debrecen
}

\begin{abstract}
Látlelet írása minden orvosi ellátásnak - így a fogorvosi ellátásnak is - a részét képezheti. A látleletet az ellátást végző orvos az ellátási lap alapján a nyomozó hatóság és a bíróság részére hivatalból, a sérült kérésére magánúton köteles kiállítani. A látlelet az orvosi vizsgálat során észleltek mellett a sérülés gyógytartamára vonatkozó orvosi véleményt is tartalmazza. A sérülés leírásának hiányosságai az igazságügyi orvosszakértő munkáját kedvezőtlenül befolyásolhatják, mivel megnehezíthetik a szakértői vélemény elkészítését. A szerzők 147, a Pécsi Tudományegyetemrôl és a Debreceni Egyetemről származó, fogászati és szájsebészeti ellátások után kiállított látlelet retrospektív vizsgálatát végezték el a nyelvészet, a fogászat, a traumatológia, a büntetőjog és az igazságügyi orvostan szakmai szempontjai szerint. A leletekben dokumentált sérülések 11,1\%-a fogakat érintő sérülés, 47,7\%-a a fej-nyak régiót érintő egyéb csontsérülés és 41,2\%-a szintén ebben a régióban található lágyrészsérülés volt. A dokumentációs hiányosságokat az egy sérülésre jutó sebjellemző́k arányszámával jellemeztük, mely a vizsgált leletekben alacsony $(0,64)$ volt. A különböző csontsérülések és a fogsérülések dokumentációja között szignifikáns különbséget találtunk: fogsérülések esetén a sérülés pontos megnevezése szignifikánsan több esetben hiányzott. A fogsérülések részletes és egységes leírása azonban elengedhetetlen a sérülés gyógytartamának büntetőjogi megítéléséhez. A szerzők ismertetik orr- és fogsérülések dokumentációja esetén a szakmaspecifikus terminológiák közötti különbségek okozta nehézségeket, a hiányos sérülésleírások alapján keletkező igazságügyi orvosszakértői vélemények jogi következményeit, valamint a fogsérülések esetén alkalmazott németországi és ausztriai joggyakorlatot. A problémák jelentős részének megoldását ez alapján az egységes - az igazságügyi orvostani szempontoknak is megfelelő, valamint fogászatokon és akut ellátás során is kiválóan alkalmazható - terminológia kidolgozásában látják.
\end{abstract}

Orv Hetil. 2018; 159(51): 2154-2161.

Kulcsszavak: látlelet, fogászati sérülés, igazságügyi orvostan, terminológia, jogi eljárás

\section{Analysis of medical diagnostic reports (constats) on dental injuries from terminological, dental and forensic medical points of view}

Writing a constat is a professional skill required of every general physician and dentist. Constats are issued by healthcare providers on the investigating authority's, court's or injured person's request. This document is an official judicial evidence, a record of medical examination, and it is also a medical opinion which can determine the outcome of the subsequent legal process. Incomplete and incorrect injury descriptions make it difficult for forensic experts to form accurate and appropriate opinions. The authors examined 147 dental and oral surgical constats from the Universities of Pécs and Debrecen using multidisciplinary approach (according to terminological, dental, surgical, forensic and criminal legal aspects). Several medical reports contained mistakes in terms of inaccuracies and self-contradictions, terminology and professional medical practice. The documents included 352 injuries ( $11.1 \%$ of which were 
tooth injuries, $47.7 \%$ bone injuries and $41.2 \%$ soft-tissue injuries). The low number of attributes per injury (0.64 on average) indicates insufficient documentation. As a result of the comparative analysis, significant differences were found between the documentation of dental injuries and that of other bone injuries pertaining to their information content. We can state that physicians are most consistent when describing bone injuries, while they are less articulate about tooth injuries. The authors provide an overview of the legal consequences of injuries as well as the legal practice regarding tooth injuries in Germany and Austria, and recommend the creation of a nationwide, unified terminology for both dental and trauma departments on nasal and dental injuries.

Keywords: constat, dental injury, forensic medicine, terminology, legal procedure

Bán Á, Patonai Z, Fogarasi K, Schneider P, Boda R, Gergely P. [Analysis of medical diagnostic reports (constats) on dental injuries from terminological, dental and forensic medical points of view]. Orv Hetil. 2018; 159(51):2154-2161.

(Beérkezett: 2018. június 7.; elfogadva: 2018. június 23.)

\section{Rövidítések}

AAPD $=($ American Academy of Pediatric Dentistry $)$ Amerikai Gyermekfogászati Akadémia; CT = (computed tomography) számítógépes tomográfia; IADT = International Association of Dental Traumatology; PTE = Pécsi Tudományegyetem

Magyarországon az igazságügyi orvosszakértői vélemények az ellátás során készült sérülésleírások és az ezekből megírt látleletek utólagos vizsgálata alapján keletkeznek. A gyakorló orvosok a sérüléseket az igazságügyi orvostanban használatos egységes beosztáshoz képest kissé eltérően csoportosítják. A nézetbeli különbségekből következik, hogy a keletkezés módját és körülményeit a sérülés után több héttel, esetleg hónappal az esetek egy jelentős részében nem vagy csak korlátozottan lehet megítélni a dokumentáció alapján. Az egyes szakterületek nézetbeli eltérései a terminológiában is megjelennek. A gyakorló orvos számára az elsődleges a sérülés ellátása és az életveszély elhárítása. Ezért az akut ellátást végző orvosok ezen elveket szem előtt tartva végzik a beavatkozások dokumentálását. Az igazságügyi orvosszakértő véleményének kialakításához azonban elengedhetetlen az adott sérülés keletkezési körülményének és keletkezési mechanizmusának ismerete. E különbség egyik következménye, hogy a klinikai terminológia egy sérüléstípusként kezeli az élhatásra keletkezett „metszett és vágott” sebeket. Ezzel szemben az igazságügyi orvostan e két sérüléstípust egymástól elkülöníti a keletkezési mechanizmus szerint, figyelembe véve az eszköz tulajdonságát, elmozdulásának irányát és a sújtóerő meglétét vagy hiányát [1].

Egy 2012-ben publikált magyar-német-osztrák öszszehasonlító terminológiai tanulmány 339 magyar, 106 német és 101 osztrák látleletet vizsgált. Az igazságügyi orvosszakértő a magyarországi esetek mintegy 15\%ában, a németországi esetek $20 \%$-ában és az ausztriai esetek 19\%-ában - a klinikai dokumentáció alapján - nem vagy csak részben tudta megítélni a lágyrészsérülések keletkezési mechanizmusát [2]. A Magyarországon készült látleletek „sérülésleírás” és „kórismék” részében az ese- tek 30\%-ában a metszett és vágott sérülés kifejezéseket egymást helyettesítve használták. A látleletben a kórismét magyarul és latinul is fel kell tüntetni [3]. A vizsgált esetek 43\%-a nem tartalmazott sem latin, sem magyar diagnózist. A fennmaradó esetek 21\%-ában csak latin vagy csak magyar kórisme volt. A latin diagnózis helytelen magyarra fordítása az esetek 7\%-ában fordult elő. Az egy sérülésre jutó sérülésjellemzők száma a magyar, a német és az osztrák látleletek esetében is l-nél kevesebb volt [2]. A sérülésjellemzők alacsony száma hiányos dokumentációra utal.

A dokumentációs hiányosságok, valamint a kórismék helytelen, sokszor ellentmondásos feltüntetése - az igazságügyi orvosszakértő munkájának nehezítése mellett kedvezőtlen hatással lehet a büntetőeljárásra és a büntetés tételének meghatározására [4].

A 2012-ben készült nyelvészeti tanulmány eredménye ösztönözte a szerzőket a fogászati és szájsebészeti ellátás során keletkezett látleletek esetleges dokumentációs hibáinak felderítésére. A jelen tanulmány célja a kutatási eredmények, a gyakorlati tapasztalatok és a dokumentációs hibák büntetőjogi következményeinek ismertetése. A szerzőknek nem céljuk a dokumentációs hiányosságok polgári jogi következményeinek vizsgálata kártérítési felelősség esetében.

\section{Anyag és módszer}

A korpusznyelvészeti ${ }^{1}$ kutatás - a PTE/53707/2017 számú etikai engedélynek megfelelő módon - 147 anonimizált, a 2014 és 2017 közötti időszakból származó fogászati és szájsebészeti ellátáson készült látleletet vizsgált (1. táblázat). A leletek közül 94 a Pécsi Tudományegyetem Fogászati és Szájsebészeti Klinikájáról, 53 a Debreceni Egyetem Fogorvostudományi Karáról származott [5]. A leleteket terminológiai módszerekkel, va-

Egy nyelvre vagy szövegtípusra többé-kevésbé reprezentatívnak tekinthető, au tentikus írott szövegek elektronikus adatbázisként tárolt gyújteménye [5]. 
1. táblázat |A látleletek százalékos megoszlása a kiállítás időpontja szerint

\begin{tabular}{lcc}
\hline & Darab & $\%$ \\
\hline 2013 & 22 & 15,0 \\
2014 & 45 & 30,6 \\
2015 & 48 & 32,6 \\
2016 & 24 & 16,3 \\
2017 & 5 & 3,4 \\
Nem szerepelt & 3 & 2,1 \\
\hline Összesen & 147 & 100 \\
\hline
\end{tabular}

2. táblázat |A látleletek sérüléstípusok és véleményezett gyógytartam szerinti százalékos megoszlása

\begin{tabular}{llcc}
\hline & & Darab & $\%$ \\
\hline \multirow{2}{*}{ Sérüléstípusok } & Fogsérülés & 39 & 11,1 \\
& Egyéb csont sérülése & 168 & 47,7 \\
& Lágyrészsérülés & 145 & 41,2 \\
\hline Összesen & & 352 & 100
\end{tabular}

\begin{tabular}{llrr}
\hline Véleményezett & 8 napon belül gyógyuló & 28 & 19,0 \\
gyógytartam & 8 napon túl gyógyuló & 115 & 78,2 \\
& Nem volt & 4 & 2,7 \\
\hline Összesen & & 147 & 100 \\
\hline
\end{tabular}

lamint a WordSmith 5.0 konkordanciaszoftverrel ${ }^{2}\left(\mathrm{Ox}^{-}\right.$ ford University Press, Oxford, Egyesült Királyság) vizsgáltuk, és az így nyert adatok statisztikai feldolgozását SPSS 19-es szoftverrel (IBM, Armonk, NY, Amerikai Egyesült Államok) végeztük. A grafikonok készítéséhez a Microsoft Excel 2013 programot (Microsoft Corporation, Redmond, WA, Amerikai Egyesült Államok) használtuk.

\section{Eredmények}

A Debreceni Egyetem Fogorvostudományi Karán készült látleletek szerkezete eltért a Pécsi Tudományegyetem Fogászati és Szájsebészeti Klinikáján keletkezettek szerkezetétől. A debreceni dokumentumok az Orvosi látlelet és vélemény című formanyomtatvány szerkezetét részleteiben követték, míg a pécsiek csupán irányadónak tekintették a formanyomtatványt. A debreceni leletekben a súlyos egészségromlás kifejezés helyett - terminológiai szempontból helytelenül - egységesen az egészségrombolás szó szerepelt. Négy pécsi leletben nem nyilatkoztak a gyógytartamról.

A vizsgált látleletekben összesen 352 sérülésleírást találtunk, melyek 11,1\%-a fogakat érintő sérülés, 47,7\%-a a

\footnotetext{
${ }^{2}$ Egy adott szövegben bizonyos szavak, kifejezések együttes előfordulási gyakoriságának vizsgálata.
}

fej-nyak régiót érintő egyéb csontsérülés és 41,2\%-a szintén ebben a régióban található lágyrészsérülés volt. A három sérüléstípust terminológiai szempontok alapján egyenként és összehasonlítva is vizsgáltuk (2. táblázat).

A leletekben a fogsérülések összesen 15 különböző típusát írták le. A diagnózisok közül a fogzománc törése 5 , a fogzománc repedése 1 , a fogkorona törése 6 , a foggyökér törése 2 , a foggyökér fogmedernyúlványszél alatti törése 1 és a fogbél megnyílása (pulpaexpositio) 1 esetben szerepelt. További 2 esetben csak a törés tényét rögzítették a kórismék részben, a pontos megnevezés azonban hiányzott. 2 esetben más fogra lokalizálták a koronatörést diagnózisként a kórismében és más fogra a részletes leírásban. A luxatio kórismét 2 esetben a fog elvesztéseként fordították: ezek közül l esetben a luxatio kórisme ellenére a sérülésleírás részben subluxatio szerepelt. Egy esetben a fogak és támasztószöveteinek betegsége diagnózist is feltüntették. A zománc apró anyaghiánnyal járó sérülését 3 esetben a fogkorona töréseként kórismézték. A fogtörés eseteinek felénél nem tüntették fel a kórismékben, hogy a fog mely része volt érintett. Egy esetben fordult elő eltérő oldalmegjelölés a kórismék és a részletes leírás részben. Fogsérülés esetén a látleletek csupán 43,6\%-a tartalmazott a fogazat általános állapotára vonatkozó adatot.

Fogsérülést összesen 5 esetben véleményezett az ellátó orvos nyolc napon túl gyógyuló sérülésnek. Egy esetben a beteg 3 fogának fogzománcot érintő anyaghiányos („zománcdarab kitörése”) sérülését - a 16-os számú módszertani levél iránymutatásával ellentétben - nyolc napon túli sérülésként írták le. Egy másik esetben 3 fog gyökerének törését szintén nyolc napon túl gyógyuló testi sérülésnek véleményezték, mivel a fogakat több fogmegtartó mútét ellenére eltávolítani kényszerültek. Nem találtunk a fogazat általános állapotára vonatkozó információt azokban a látleletekben, melyekben a fogak sérülésének gyógytartamát nyolc napon túlinak véleményezték.

A vizsgált látleletekben 14 különböző diagnózis jelölt lágyrészsérülést. A lágyrészek sérüléseit rögzítő látleletek csupán $45,4 \%$-a tartalmazott a sérülés jellemzőire vonatkozó adatot. Olyan esetek is előfordultak, melyekben „sérülésre utaló” kifejezéseket (például sérülés, vérzés, nyílt seb) találtunk, azonban nem rögzítettek sérüléstípust jelölő kórismét vagy részletes leírást. A sérülések pontos számát 8 látlelet leírás része nem tartalmazta; egynél több sérülésre a kórismék többes számú alakjaiból (például repesztett sebek, horzsolások stb.) következtethettünk. A vizsgált látleletekben a sebjellemzők közül a méret került a leggyakrabban leírásra, összesen 54 esetben. Az egyéb sebjellemzők tekintetében az arány sokkal rosszabb volt (3. táblázat).

A látleletek leírás részeiben összesen 45 esetben rögzítettek vérgyülemet (haematomát). Ezek közül a haematoma színére csak egy alkalommal történt utalás (kékeslilás). Az egy sérülésre jutó sérülésjellemzők száma a vizsgált anyagban 0,64 volt (4. táblázat). 
3. táblázat |A látleletekben előforduló sebjellemzők száma

\begin{tabular}{lc}
\hline Sebjellemzők & Darab \\
\hline Seb mérete & 54 \\
Seb mélysége & 16 \\
Lefutás iránya & 8 \\
Sebszélek & 7 \\
Sebzugok & 2 \\
Sebfalak & 3 \\
Szövethidak & 1 \\
\hline Összesen & 91 \\
\hline
\end{tabular}

4. táblázat $\mid$ Az egy lágyrészsérülésre jutó sebjellemzők száma a jelen fogászati látleleteken, a korábban vizsgált baleseti sebészeti látleletekkel összehasonlítva

\begin{tabular}{lc}
\hline & Sebjellemzők száma \\
\hline Magyar fogászati és szájsebészeti látleletek & 0,64 \\
$\begin{array}{l}\text { Magyar baleseti sebészeti és háziorvosi } \\
\text { látleletek* }\end{array}$ & 0,87 \\
Német baleseti sebészeti látleletek* & 0,55 \\
Osztrák baleseti sebészeti látleletek* & 0,28 \\
\hline
\end{tabular}

*A 2012-es tanulmány eredményei [2].

5. táblázat |A törések lokalizáció szerinti százalékos megoszlása

\begin{tabular}{lcc}
\hline & Darab & $\%$ \\
\hline Mandibula & 54 & 40,0 \\
Maxilla & 19 & 14,1 \\
Os nasale & 10 & 7,4 \\
Orbita & 10 & 7,4 \\
Os zygomaticum & 31 & 23,0 \\
Arcus zygomaticus & 5 & 3,7 \\
Os frontale & 1 & 0,7 \\
Nem meghatározható & & 3,7 \\
\hline Összesen & 5 & 100 \\
\hline
\end{tabular}

*Pontatlan leírás és kórisme miatt a törés lokalizációja nem egyértelmű.

A magyar és a latin kórisme jelentése 8 lágyrészsérülés esetében különbözött. A lágyrészek zúzódását 6 esetben vulnus contusumként (zúzott sebzés), a felszínes horzsolást 2 esetben vulnus abrasumként fordították latinra. A vizsgált anyagban metszett sérülés nem szerepelt. A leírásban és a kórismében rögzített oldalmegjelölés 3 esetben különbözött.

A látleletek sérülésleírás részei összesen 167 csontsérülést tartalmaztak. A csont törése 135, repedése (fissura) 3 , benyomatos törése (infractio) pedig 1 esetben szerepelt diagnózisként. Lokalizáció szerint a legnagyobb arányban a mandibula és az os zygomaticum volt érin- tett, míg az orrcsont és az orbita törése 7,4\%-ban fordult elő (5. táblázat).

$\mathrm{Az}$ orrcsont sérülésénél 3 látlelet kórisme részében fractura szerepelt, míg a leírás részben a repedés (fissura) terminus került rögzítésre. További 2 esetben a leírások az orrcsont törésére utaltak, ugyanakkor a kórismék között az orrcsont törését nem rögzítették. Oldaltévesztés 1 esetben történt. A leírásban pontosan lokalizált töréshez 5 esetben társítottak pontatlan kórismét (például a mandibula törésének leírásához tartozó kórisme az arckoponya törése volt).

A statisztikai elemzést nehezítette, hogy számos fog-, csont- és lágyrészsérülés esetében hiányzott a leírás és/ vagy részlegesen, esetleg teljesen a kórisme. A látleletek 3,1\%-ában nem szerepelt sérülésleírás; a latin kórismék 44,9\%-ban, a magyar kórismék pedig 50\%-ban hiányoztak.

Khi-négyzet-próbával vizsgáltuk a lágyrész-, a fog- és a csontsérülésekről készült látleletek közötti különbséget a látleletek egyes szerkezeti egységeinek kitöltöttsége tekintetében. A legnagyobb százalékban csonttörések esetén szerepelt a sérülés típusát leíró szakkifejezés a leírásban, valamint a magyar és a latin kórismében egyaránt. Szignifikáns különbséget $(\mathrm{p}<0,05)$ találtunk a leletek kitöltöttsége tekintetében a fogsérülések és a csontsérülések között mind a látleletek sérülésleírás részében, mind pedig a magyar és a latin kórismékben. (Kitöltöttség tekintetében a leírás fogsérülés-csontsérülés: $\mathrm{khi}(1)=$ $60,65 \mathrm{p}=6,82 \mathrm{e}-15, \mathrm{p}<0,05$; latin $\mathrm{dg}$. fogsérülés-csontsérülés: $\operatorname{khi}(1)=40,72, \mathrm{p}=4,12 \mathrm{e}-17, \mathrm{p}<0,05$; magyar dg. fogsérülés-csontsérülés: $\operatorname{khi}(1)=80,29 \mathrm{p}=3,23 \mathrm{e}-19$, $\mathrm{p}<0,05)$.

\section{Megbeszélés}

Összefoglalva megállapítható, hogy a vizsgált fogászati látleletek a nem fogászati magyar nyelvű látleletekkel összehasonlítva terminológiai szempontból ugyan következetesebbek, azonban a lágyrészsérülések leírásai tekintetében kevésbé részletesek (4. táblázat).

A vizsgált anyagban előforduló törések közül az orrcsont törésének leírásában és kórismézésében mutatkozott a leginkább terminológiai eltérés. Orrcsonttörés esetén a repedés (fissura) megnevezés félreértelmezhető lehet. A fissura a töréshez hasonlóan a csontállomány folytonosságmegszakadásával jár, tehát törésként véleményezhető, ami nyolc napon túl gyógyuló sérülést jelent. A repedés azonban kisebb erejű erőbehatást feltételez, így megnevezésére kevésbé lenne megtévesztő a fractura incompleta használata.

Az igazságügyi orvosszakértő szempontjából nehezíti az orrcsont törésének dokumentáció alapján történő megítélését, hogy az ellátást végző orvos véleménye sok esetben különbözik a radiológusétól. Ennek egyik oka lehet, hogy vannak olyan folyamatos ellátást biztosító ambulanciák, melyek mellett ügyeleti időben nem áll rendelkezésre radiológus szakorvos. Tehát az elsődleges 
véleményt az ellátó orvos adja, míg a radiológus a leletezést később végzi, így nem mindig van lehetőség konzultációra.

A sürgősségi ellátás során rendelkezésre álló képalkotó vizsgálatok segítségével a törések egy része nagy biztonsággal diagnosztizálható, azonban bizonyos töréstípusok esetében a megítélés nehézkes vagy nem lehetséges. Az arckoponyát ért sérülések diagnosztikájában bizonyos esetekben a hagyományos röntgenfelvétel a csontok egymásra vetülése miatt korlátozott értékű, ezért sokkal több információt nyújt a CT-vizsgálat. Fogászati szempontból a panorámaröntgen-felvétel vagy cone-beam (kúpsugaras) CT, míg az izolált orrsérülések (törések) diagnosztikájában a hagyományos röntgenfelvétel elvégzése ajánlott. Az orrcsontról készült felvételek egy irányból készülnek. Általános elv, hogy a törés kizárásához legalább kétirányú felvétel készítése szükséges. Az orrcsont elhelyezkedése miatt a második irány az egymásra vetülés miatt nem értelmezhető, emellett az orrcsont röntgenmorfológiája is rendkívül nagy variabilitást mutat. A problémát nem a lépcsóképződéssel járó, kiemelést igénylő esetek jelentik, hanem az elmozdulás nélküli törések, repedések diagnosztikája. Az ellátó orvos a fizikális vizsgálat eredményét és a röntgenfelvételt együtt értelmezi, majd nyilatkozik a törésről vagy a törés gyanújáról, esetleg a látottakat repedésként írja le. Amennyiben az első felvételen látottak felvetik a törés gyanúját, akkor a fenti megfontolásból kiindulva azt szerencsésebb gyanúként kezelni, mint fissuraként leírni. Törés gyanúja esetén a kontrollfelvételt követően érdemes a gyógytartamra vonatkozóan nyilatkozni. A szakirodalom ezekben a hatósági eljárást eredményező esetekben a cone-beam CT vizsgálatot javasolja az információtöbblet és a háromdimenziós rekonstruálhatóság miatt [6-9]. Ez a vizsgálattípus azonban sajnálatos módon jelenleg csak kevés helyen érhető el.

A dokumentációban félrevezető lehet a folytonosságmegszakadással nem járó sérülések vulnusként való latin fordítása. A leletet kiállító orvosok a lágyrészek zúzódását többször vulnus contusumként (zúzott sebzés) írták le. A vulnus terminus folytonosságmegszakítással járó sérülést jelöl, míg a contusio (hámzúzódás) folytonosságmegszakadással nem járó sérülésre utal. A két kifejezés szinonim használata terminológiai szempontból nem javasolt. A fenti elgondolásból következik, hogy a vulnus kifejezés helytelen és megtévesztő a hámhorzsolás ${ }^{3}$ eseteiben is, mivel abrasiónak (hámhorzsolás) a hám különböző mélységü rétegeinek anyaghiánnyal járó sérülését nevezzük. Ennél a sérüléstípusnál a hám alatti szövetek nem érintettek. A mélyebb, subcutan szöveteket is érintő sérülésnél a vulnus lacerum (szakított sebzés) összetétel alkalmazható. Haematoma leírásakor csak egyetlen leletben tettek utalást annak színére. A vérgyülem és a bevér-

3 A vizsgált látleletekben több esetben vulnus abrasumként fordították latinra a hámhorzsolást. zés (suffusio) színe azonban fontossággal bír az igazságügyi orvosszakértő szempontjából, hiszen segítségével megbecsülhető a sérülés keletkezésének ideje. Általánosságban elmondható továbbá, hogy a hiányos, nem leíró jellegű (például nyílt seb) lágyrészsérülés-leírásokból a későbbiekben bizonytalan - valószínúségi - szakértői vélemény készíthető.

A fogsérülés és/vagy csontsérülés eseteiben a látleletek között a részletesség tekintetében szignifikáns különbséget találtunk. Feltehetően a csontsérülések terminológiája az, amely mind latin, mind pedig magyar nyelven a leginkább kikristályosodott és ismert a gyakorló orvosok körében. A fogsérülések megnevezéseivel kapcsolatban azonban kevésbé gyakran foglalnak állást. További problémát jelent, hogy a fogtörések latin kórisméi nem egységesek. A fogzománcot érintő töréseket bizonyos esetekben a fogkorona komplett vagy inkomplett töréseként kórismézték. A pontatlan megnevezés alapján nem lehet megítélni, hogy a törés csak a zománcra vagy a zománcra és a dentinre terjedt, vagy pedig a zománc, a dentin és a pulpa egyaránt érintett volt. A fogkorona-sérülés kiterjedésének mértéke meghatározza az ellátást és a későbbi szövődmények kialakulásának lehetőségét. Foggyökértörés esetében a gyökér és a fog megtartásának esélyét a törés elhelyezkedése befolyásolja. Attól függően, hogy a sérülés a fog gyökerének mely harmadát érinti, a fog megmentésére orthodontiai extrusióval, csonkhosszabbító mútéttel vagy a funkció helyreállítására gyökérkezelés után csapos felépítmény készítésével tehetünk kísérletet [10-12]. A foggyökeret ért sérülés későbbi következményeként számolnunk kell bizonyos szövődmények kialakulásának reális veszélyével, például gyulladásos reszorpció, pulpanecrosis és -reszorpció, obliteráció [11], melyek végeredménye a fog elvesztése lehet.

A maradó fogak sérüléseinek klasszifikációjában és kezelésében a nemzetközi szakirodalom az IADT Guidelines [13] vagy az Andreasen's Dental Trauma Guide [14] használatát javasolja $[15,16]$. Gyermekkorban a tejfogakat és fogváltást követően a maradó fogakat érintő sérülések beosztásában és kezelésében az AAPD ajánlásai az iránymutatóak [17-20]. A fogvesztés bekövetkezhet közvetlenül a sérülés után vagy hónapokkal, esetleg évekkel később, a sérülés következményeként kialakult szövődmények miatt. A sérülés dokumentációja során ezért fontos részletesen nyilatkozni arról, hogy a fogak és/vagy fogrészek elvesztését közvetlenül a sérülés okozta, vagy az egy állcsontot érintő törés következménye [21].

A gyakorlatban a fog teljes luxatiója esetén kísérletet lehet tenni a fog fogmedernyúlványba történő visszahelyezésére, amennyiben azt a beteg általános állapota (például politraumát szenvedett sérült), a fogazat általános állapota, a fogvesztés óta eltelt idő, valamint a fog szállítási és tárolási körülményei megengedik. Az említett körülmények ismeretében és a magyar lakosság fogazatának rossz állapota miatt a fog visszahelyezése sajnálatos mó- 
don csak kevés esetben lehetséges. A különböző fog(például destruált fog) és fogágybetegségek (például parodontitis) következtében a fog(ak) törése vagy elvesztése kisebb erőbehatásra is bekövetkezhet. Az orvosi dokumentációban részletesen rögzíteni kell minden olyan kórállapotot és egyéb körülményt (korábbi gyökértömések, szisztémás betegség, például leukaemia, valamint gyógyszerek, például biszfoszfonátok stb.), melyek elősegíthetik a fog elvesztését. Az orvosszakértőnek ugyanis nyilatkoznia kell arról, hogy a fogvesztés bekövetkezhetett-e egészséges fogágy mellett, jól rögzített fogak esetében is.

A parodontitis egyik következménye a csontállomány csökkenése. A mára elavult „fogmedernyúlvány sorvadása" kifejezés helyett objektívebb lenne a csontvesztés százalékos arányának általános használata. A százalékos arányok ismeretében nemcsak összehasonlításra lenne lehetőség, hanem meghatározó lehetne, hogy a parodontitis milyen mértékben növelte az adott erőbehatás mellett a fogvesztés veszélyét. A foggyökértörésnél az elhelyezkedéstől (fogmedernyúlványszél alatti) vagy a társsérülésektől (melyek a fogmedernyúlvány törésével társulnak) függetlenül speciális beavatkozások ellenére is nagy a fog elvesztésének reális lehetősége.

\section{Büntetőjogi vonatkozások}

A fogászati sérülésekrôl készült dokumentáció részletessége hatással lehet a sérülések büntetőjogi megítélésére. $\mathrm{Az}$ elszenvedett sérülés súlyossága (gyógytartama) szerint nyomozás indulhat magánindítványt követően könnyű vagy hivatalból súlyos testi sértés miatt. E tények a későbbi bírósági szakban súlyosbíthatják a kiszabott büntetést. A büntetés tételének megállapításakor meghatározó az adott cselekménynek, az elkövető bûnösségének és az egészségkárosodásnak a mértéke. A részletes dokumentáció segít az elkövető szándékának és a következmények felróhatóságának megítélésében.

A büntetőjog megkülönböztet könnyü és súlyos testi sértést. A könnyü testi sértés általában kevésbé súlyos következménnyel jár, és gyógytartama rövidebb. Súlyos testi sértés esetében lényegesen hosszabb gyógyulási idővel kell számolni. Súlyos testi sértés a magyar büntetőjogban nyolc napon túl gyógyuló sérülés [22], az osztrák büntetőjogban 24 napon túl gyógyuló sérülés [23], a német büntetőjogban pedig tartós egészségkárosodás esetén [24] állapítható meg.

A fogak sérülése esetében nem érhető el teljes gyógyulás, ezért a könnyü és a súlyos testi sértés kategóriáinak megkülönböztetéséhez új kritériumrendszer felállítása szükséges. A súlyos testi sértés ténye csak az összes elszenvedett sérülés figyelembevételével állapítható meg. E tekintetben a magyar büntetőjog máig meglehetősen elnagyolt, mivel a súlyos testi sértést csak a több, mint 3 fog részleges vagy teljes elvesztése jelenti (vö. [3]).

Az osztrák jogban a fogvesztés csak abban az esetben számít súlyos testi sértésnek, ha a fogazat a sérülés követ- keztében minőségi károsodást szenved (például a rágófunkció). Ezért a súlyos testi sértés ténye már kettő, közvetlenül egymás mellett elhelyezkedő fog esetében is megállapítható [25]. A német büntetőjog a fog elvesztését alapvetően könnyű testi sértésként értékeli [26], mivel súlyos testi sértés a törvény szó szerinti értelmében csak a „végtagok elvesztése” esetén állapítható meg.

A német jogban a könnyú testi sértés esetén kiszabható maximális büntetési tétel azonban - a magyar és az osztrák büntetőjogtól eltérően - 5 év szabadságvesztésig terjedhet. A fogvesztés miatt bekövetkezett károsodásokat súlyosbító tényezőként figyelembe lehet venni a büntetés kiszabásakor. A német és az osztrák büntetőjogban a sértett arcának „tartós eltorzulását“ okozó fogvesztés súlyos testi sértésnek számít. Emiatt szükség lehet a sértett arcának a sérülés előtti és utáni leírására. Napjainkban a korszerü fogpótlási technikáknak köszönhetően az „eltorzulás“ mint tényállási elem elvesztette jelentőségét, hiszen a sérülés következtében kialakult előnytelen megjelenés megszüntethető. A „tartós eltorzulást" mint szempontot csak abban a különleges esetben lehet figyelembe venni, ha a sértettnél a korrekciós fogászati beavatkozások magas kockázat miatt nem végezhetók el [27].

Az erőbehatás mértékének és az elkövető szándékának megállapításában rendkívüli fontossággal bír a részletes fogászati lelet felvétele a sérülés ellátásakor. A kellően alapos dokumentáció - a sérülés mellett - a fogazat általános állapotát is részletesen leírja. A büntetés kiszabásakor figyelembe kell venni a cselekmény körülményeit és következményeit. Továbbá vizsgálni kell, hogy a sérülés következményei kizárólag a bántalmazással mutatnak-e összefüggést, vagy azokat egyéb tényező is befolyásolhatta. Például a sérülés csak nagy erőbehatás következtében - a kérdéses testtájékon súlyosabb sérülés okozására is alkalmas eszköz használatával - keletkezhetett, vagy esetleg kisebb erőbehatás okozhatta. Az elkövető csak abban az esetben büntethető szándékosan elkövetett könnyü vagy súlyos testi sértés miatt, ha tudatában volt a sértett kárára okozott sérülés következményeinek, vagy azokba legalábbis belenyugodott. Kisebb erőbehatás esetén szükségszerü feltenni a kérdést, hogy az elkövető - a következmények súlyosságára tekintettel - nem gondatlanságból cselekedett-e. Kérdéses ugyanis, hogy az elkövetőnek kell-e számolnia a gyengén rögzített fogak csekély erőhatásra történő elvesztésének lehetőségével.

\section{Következtetés}

A magyarországi gyakorlatban az izolált és a társsérülésként előforduló, a fej-nyak régiót és a szájüreget érintő sérülések első észlelését és ellátását - a folyamatos ellátást biztosító - traumatológiai és/vagy fül-orr-gégészeti ambulanciák végzik. Így a szájüreget érintő sérülések első észlelése csupán az esetek elenyésző hányadában történik fogászati és szájsebészeti szakrendeléseken. Ennek egyik oka, hogy folyamatos ellátást csak a II. és III. progresszi- 
vitási szintü arc-, állcsont- és szájsebészeti osztályok biztosítanak, ami az egyetemi klinikákat és a megyei kórházak egy részét jelenti. A legtöbb város biztosít fogászati ügyeletet, de ezek többnyire a munkaszüneti és ünnepnapokon nyújtott pár órás rendelési időt foglalják magukban. A fogászati betegellátást - beleértve az ügyeleti ellátást is - végző rendelők nem feltétlenül rendelkeznek röntgenkészülékkel. A röntgenkészülék a fogászati alapés szakellátásnak nem minimumfeltétele [28].

Az akut ellátás során általában nem a szájnyálkahártya, a nyelv és az ajak folytonosságmegszakadással járó sérüléseinek ellátása jelenti a problémát. Nehézséget sokkal inkább az okoz, hogy az első ellátást végző baleseti sebész vagy fül-orr-gégész szakmai ismereteinek nem képezik részét a sérülések pontos megítélését lehetővé tévó fogászati ismeretek. Ezek a szakemberek eszközök, szaktudás és sokszor speciális képalkotó diagnosztika hiányában nem tudják megítélni a foghúst ért sérülések mögött meghúzódó társsérüléseket: azt, hogy egy luxatio vagy subluxatio az általános állapot vagy az elszenvedett sérülés következménye-e, illetve hogy az elvesztett fog megmenthető-e vagy sem. A fogakat és az orrot ért sérülések ellátásában és megítélésében kívánatos lenne egy egységes nézőpont kialakítása, illetve olyan betegutak szervezése, amelyek lehetővé teszik - a szakmai irányelveket is szem előtt tartva - a rövid időn belüli szakmaspecifikus ellátást.

A különböző sérülések, így a szájüreget és a fej-nyak régiót érintő sérülések szakértésében is egyedül az Országos Igazságügyi Orvostani Intézet 16. számú módszertani levele irányadó (érvényességét vesztette, de jelenleg is hivatkozási alapnak tekintendő). A módszertani levél a szájüreget és a fogakat érintő sérülésekre vonatkozóan nem tartalmaz részletes iránymutatást. A módszertani levél szerint nyolc napon belül gyógyuló sérülésnek számít az „1-3 fog meglazulása, luxatiója, a fogkorona letörése vagy a fogaknak a fogmedernyúlvány törése nélküli elvesztése". Hiányzik azonban a fogvesztés definíciója, valamint a fogászati és szájsebészeti vonatkozású sérülések nyolc napon túl gyógyuló eseteinek felsorolása. A fogvesztést befolyásoló tényezők közül csak a „fogmedernyúlvány sorvadását” és a „sorvadt pillérfogat” említi. A fogak elvesztését maradandó fogyatékosságként értékeli, azzal a megjegyzéssel, hogy azok „pótlása funkcionális és esztétikai javulással járhat”.

A szerzők véleménye szerint indokolt lenne a fogvesztést nyolc napon túl gyógyuló testi sérülésnek tekinteni. Szintén nyolc napon túli testi sérülésnek javasolt véleményezni a foggyökértörést - a fog teljes luxatiójához hasonlóan -, amennyiben a későbbiekben a fog elvesztésével jár. A fogvesztéssel nem járó fogsérülések - a jó funkcionális és esztétikai helyreállítási lehetőségek miatt - nyolc napon belül gyógyuló testi sérüléseknek tekinthetők. Kívánatos lenne részletesen rögzíteni azon szájüregi állapotokat és sérülés okozta késői szövődményeket, melyek a fog elvesztéséhez vezethetnek. Az igazságügyi orvosszakértői véleményben minden kórállapo- tot figyelembe kell venni, amely hozzájárulhat egy súlyosabb - büntetőjogi szempontból nyolc napon túl gyógyuló - sérülés létrejöttéhez. A fogak csökkent rögzítettsége esetében fontos a részletes és egységes dokumentáció, mivel fogvesztés esetén a bíróság ezeket enyhítő körülményként figyelembe veheti. A fogvesztést kedvezőtlenül befolyásoló körülmények a büntetőjogi gyógytartamot nem befolyásolják.

A fogsérülésekkel kapcsolatos látleletek következetes, a fogazat általános állapotára is kiterjedő, egységes terminológia alapján történő kitöltése nagymértékben segítené a fej-nyak régiót és a szájüreget ért sérülések igazságügyi orvosszakértői megítélését.

Anyagi támogatás: A közlemény megírása, illetve a kapcsolódó kutatómunka anyagi támogatásban nem részesült.

Szerzôi munkamegosztás: B. Á.: A 16-os számú módszertani levél fogsérülésekkel és fogvesztéssel kapcsolatos részeinek elemzése az empirikus vizsgálat eredményeinek tükrében, a módosítására vonatkozó javaslatok megfogalmazása. P. Z.: Az orrcsont és a fogak sérüléseinek ellátásával kapcsolatos gyakorlati problémák megfogalmazása a traumatológus, illetve a gyakorló orvos szemével, a tanulmány szerkesztése. F. K.: Az empirikus nyelvészeti vizsgálat elvégzése és az eredmények terminológiai szempontú értékelése. S. P.: A fogászati sérülések kontrasztív büntetőjogi megítélése. B. R.: Együttmúködés a fogvesztés javasolt definíciójának megalkotásában, segítségnyújtás az empirikus vizsgálatban. G. P.: Az empirikus vizsgálat eredményeinek értékelése és a 16-os számú módszertani levélre vonatkozó módosítási javaslat indoklása igazságügyi orvostani szempontból. A cikk végleges változatát valamennyi szerző elolvasta és jóváhagyta.

Érdekeltségek: A szerzőknek nincsenek érdekeltségeik.

\section{Köszönetnyilvánítás}

Köszönet illeti Csoboth Ildikót a statisztikai elemzésben nyújtott segítségéért.

\section{Irodalom}

[1] Fogarasi K. Terminological problems of types and descriptions of injuries in accident surgical diagnostic reports. In: Silye M. (ed.) Porta Lingua. [Sebtípusok, sebleírások terminológiai problémái traumatológiai látleleteken. In: Silye M. (szerk.) Porta Lingua. Tudományterületek és nyelvhasználat.] Szaknyelvoktatók és Kutatók Országos Egyesülete, Debrecen, 2010; pp. 121-138. [Hungarian]

[2] Fogarasi K. Limited forensic assessability of soft tissue injuries. Contrastive terminological analyses of Hungarian, Austrian and German medical diagnostic reports. PhD Dissertation. Pécs, University of Pécs, Faculty of Health Sciences, 2012.

[3] Administrative Regulation No. 16 on the forensic medical assessment of injuries and health impairment of the Hungarian Insti- 
tute of Forensic Medicine. [Az Országos Igazságügyi Orvostani Intézet 16. számú módszertani levele a testi sérülések és egészségkárosodások igazságügyi orvosszakértői véleményezéséról (1997. évi CLIV. törvény az egészségügyről).] Egészségügyi Közlöny, 7/1998; 619. Available from: http://igor.diogenes. hu/download/modszlev/16_mszlev.pdf [Hungarian]

[4] Schneider PM. Die klinisch-medizinische Dokumentation von vorsätzlichen Körperverletzungsdelikten durch stumpfe und scharfe Gewalt im Strafverfahren und die Folgen unzureichender Beschreibung und unpräziser Terminologie. PhD Dissertation. Pécsi Tudományegyetem, Állam- és Jogtudományi Doktori Iskola, Pécs, 2017.

[5] Szirmai M. Introduction to corpus linguistics. [Bevezetés a korpusznyelvészetbe.] Tinta Könyvkiadó, Budapest, 2005; p. 18. [Hungarian]

[6] Ireland AJ, McNamara C, Clover MJ, et al. 3D surface imaging in dentistry - what we are looking at. Br Dent J. 2008; 205: 387-392.

[7] Dawood A, Patel S, Brown, J. Cone beam CT in dental practice. BDJ 2009; 207: 23-28.

[8] Jaju PP, Jaju SP. Clinical utility of dental cone-beam computed tomography: current perspectives. Clin Cosmet Investig Dent. 2014; 6: 29-43.

[9] Palomo L, Palomo JM. Cone beam CT for diagnosis and treatment planning in trauma cases. Dent Clin North Am. 2009; 53: 717-727.

[10] Malhotra N, Kundabala M, Acharaya S. A review of root fractures: Diagnosis, treatment and prognosis. Dent Update 2011; 38: 615-616, 619-620.

[11] Saoud TM, Mistry S, Kahler B, et al. Regenerative endodontic procedures for traumatized teeth after horizontal root fracture, avulsion, and perforating root resorption. J Endod. 2016; 42: 1476-1482.

[12] Paryani K, Kim SG. Regenerative endodontic treatment of permanent teeth after completion of root development: a report of 2 cases. J Endod. 2013; 39: 929-934.

[13] International Association of Dental Traumatology. Dental Trauma Guidelines 2012. Available from: http://aidt-dentaltrauma. org

[14] Dental Trauma Guide. Evidence Based Treatment Guide. Available from: http://dentaltraumaguide.org

[15] Trope M. Avulsion of permanent teeth: theory to practice. Dent Traumatol. 2011; 27: 281-294.

[16] Andreasen JO, Andreasen FM, Andersson L. (eds.) Textbook and color atlas of traumatic injuries to the teeth. 4th edition. Wiley-Blackwell/Munksgaard Publishing Company, Oxford, 2013.
[17] American Academy of Pediatric Dentistry (AAPD). Guideline on Management of Acute Dental Trauma. Reference Manual 2012; 34: 230-238.

[18] DiAngelis AJ, Andreasen JO, Ebeleseder KA, et al. International Association of Dental Traumatology guidelines for the management of traumatic dental injuries: 1. Fractures and luxations of permanent teeth. Dent Traumatol. 2012; 28: 2-12.

[19] Andersson L, Andreasen JO, Day P, et al. International Association of Dental Traumatology guidelines for the management of traumatic dental injuries: 2 . Avulsion of permanent teeth. Dent Traumatol. 2012; 28: 88-96.

[20] Malmgren B, Andreasen JO, Flores MT, et al. International Association of Dental Traumatology guidelines for the management of traumatic dental injuries: 3 . Injuries in the primary dentition. Dent Traumatol. 2012; 28: 174-182.

[21] Fritze E. Die ärztliche Begutachtung. Springer, Berlin, 2012; p. 752.

[22] Act C of 2012 on the Criminal Code. [2012. évi C. törvény a Büntető Törvénykönyvről.] 164. \$. Available from: https://net. jogtar.hu/jr/gen/hjegy_doc.cgi?docid=Al200100.TV [Hungarian]

[23] Das österreichische Strafgesetzbuch (StGB) Bundesgesetz vom 23. Jänner 1974 über die mit gerichtlicher Strafe bedrohten Handlungen. $\$ 84$. Available from: https://www.ris.bka.gv.at/ GeltendeFassung.wxe?Abfrage $=$ Bundesnormen\&Gesetzesnum mer $=10002296$

[24] Das deutsche Strafgesetzbuch (StGB) zuletzt geändert durch Gesetz vom 30. 09. 2017 (BGBl. I S. 3532) m.W.v. 13. 10. $2017 ; \$ 226$

[25] Oberster Gerichtshof, Urteil vom 16. 06. 1981 - 9 Os 60/81.

[26] Das deutsche Strafgesetzbuch (StGB) zuletzt geändert durch Gesetz vom 30. 09. 2017 (BGBl. I S. 3532) m.W.v. 13. 10. 2017; $\$ 223$.

[27] Bundesgerichtshof, Urteil vom 29. 02. 1972 - 5 StR 400/71, in: NJW 1972; 1143-1144.

[28] Decree No. 60/2003 (20. 10.) of the Ministry of Health, Social and Family Affairs on the minimum technical requirements provioling health services. (60/2003. (X. 20.) ESzCsM rendelet az egészségügyi szolgáltatások nyújtásához szükséges szakmai minimumfeltételekről.] Available from: https://net.jogtar.hu/ $\mathrm{jr} / \mathrm{gen} / \mathrm{hjegy}$ doc.cgi?docid=a0300060.esc [Hungarian]

(Bán Ágnes dr., Pécs, Dischka G. u. 1., 7621 e-mail: jobbfelso@gmail.com) feltéve, hogy az eredeti szerző és a közlés helye, illetve a CC License linkje és az esetlegesen végrehajtott módositások feltüntetésre kerülnek. 